\author{
Renata Rettinger \\ Uniwersytet Pedagogiczny w Krakowie, Polska - Pedagogical University of Cracow, Poland \\ MatgorZATA Bajgier-KowalsKa \\ Krakowska Akademia im. A.F. Modrzewskiego, Polska - Andrzej Frycz Modrzewski Krakow University, Poland
}

\title{
Eventy jako element różnicujący produkt turystyczny miast - studium przypadku Pistoi (Włochy)
}

\section{Events as an Element Differentiating the Tourism Product of Cities. The Case of Pistoia (Italy)}

Streszczenie: Dynamiczny rozwój turystyki w wielu regionach świata powoduje wzrost konkurencji, co z kolei prowadzi do wielu zmian w ofertach turystycznych. Turystyka jest alternatywą dla innych rodzajów działalności gospodarczej. Dotyczy to jednostek przestrzennych o różnej wielkości, w tym miast, dla których funkcja turystyczna może stać się mechanizmem lokalnego rozwoju oraz ochrony dziedzictwa kulturowego i naturalnego. Jako wyjątkowe atrakcje turystyczne coraz częściej postrzega się festiwale i uroczystości publiczne oraz wiele innych specjalnych wydarzeń, tworzących wizerunek miejsca. Głównym celem niniejszego artykułu jest przedstawienie potencjału turystycznego miasta historycznego oraz możliwości dalszego rozwoju ruchu turystycznego w świetle aktualnych tendencji światowego rynku turystycznego. Artykuł zawiera również próbę analizy struktury produktu turystycznego miasta Pistoia dokonaną na podstawie jego położenia jako sąsiada tak dużych ośrodków turystycznych, jak Florencja czy Piza.

\begin{abstract}
The dynamic development of tourism in many regions of the world causes competition boost which, in turn, leads to a variety of changes in tourist offers. Tourism is an alternative for other types of economic activity, this relates to spatial units of diverse area, including cities. The tourist function can become the mechanism of local development for cities and the protection of the cultural and natural heritage. Festivals and public celebrations, together with a variety of other special events are increasingly seen as unique tourist attractions and as destination image makers. The main goal of the article is to present the tourist potential of a historical city and the possibilities of further development of tourist movement in light of the current tendencies of the world tourist market. The paper also includes an attempt to analyse the structure of a tourist product of the city of Pistoia basing on its location as a neighbour of such large tourist centers as Florence or Pisa.
\end{abstract}

Słowa kluczowe: autentyczność; turystyka eventowa; turystyka kulturowa; turystyka miejska

Keywords: authenticity; cultural tourism; events tourism; urban tourism

Otrzymano: 27 grudnia 2017

Received: 27 December 2017 
Zaakceptowano: 25 września 2018

Accepted: 25 September 2018

\section{Sugerowana cytacja/Suggested citation:}

Rettinger, R., Bajgier-Kowalska, M., (2018). Eventy jako element różnicujący produkt turystyczny miast - studium przypadku Pistoi (Włochy). Przedsiębiorczość - Edukacja [Entrepreneurship - Education], 14, 270-281. DOI: 10.24917/20833296.14.20

\section{Wstęp}

Wśród wielu form turystyki kulturowej turystyka eventowa jest jedną z najczęściej podejmowanych i najszybciej rozwijających się. Eventy stanowią obecnie jedną z głównych kategorii produktu turystycznego i dla wielu turystów stanowią jeden z celów podróży. Obserwuje się potencjalne zależności pomiędzy eventem a rynkiem turystycznym wybranej destynacji, ponieważ organizacja eventów stanowi obecnie jeden z głównych czynników determinujących rozwój turystyki kulturowej w miastach. Eventy o charakterze kulturowym (czy kulturalnym) stały się elementem marketingowym miasta w kontekście uzyskania i utrzymania przewagi konkurencyjnej.

Głównym celem niniejszego artykułu jest ukazanie potencjału turystycznego miasta Pistoi, położonego w prowincji Toskania we Włoszech, oraz możliwości wzrostu wielkości ruchu turystycznego w tym mieście w świetle współczesnych trendów w zakresie turystyki miejskiej. Podjęto próbę analizy produktu turystycznego miasta w kontekście jego położenia w sąsiedztwie dużych ośrodków turystycznych, którymi są Florencja czy też Piza. Sformułowano pytanie badawcze: Jak w warunkach wzmożonej konkurencji będą funkcjonować małe i średnie miasta w cieniu wielkich ośrodków turystycznych? Pistoia może być przykładem tego, jak wydarzenia kulturalne, ale także autentyczność i gościnność, stały się efektywnym narzędziem przyczyniającym się do rozwoju turystyki i elementem różnicującym regiony turystyczne czy też miasta turystyczne.

\section{Uwarunkowania rozwoju turystyki eventowej w Pistoi}

W literaturze przedmiotu dyskutuje się nad zasadnością stosowania terminu „turystyka eventowa” czy też „turystyka wydarzeń” (Zduniak, 2017). Problem polega na tym, że trudno w języku polskim odszukać określenie, które w pełni oddawałoby znaczenie terminu „event”.

Cechy odróżniające event od codziennych wydarzeń to m.in. niepowszechność występowania oraz określony z góry przez organizatora cel. Kolejną cechą eventów jest udział w nich dużej liczby osób, zarówno mieszkańców danej miejscowości, jak i przebywających tam turystów (Marczak, 2015). Dla wielu turystów wydarzenia takie o różnym charakterze stanowią jeden z głównych celów podróży, czyli organizacja eventów zwiększa wielkość ruchu turystycznego w miastach.

W literaturze można się doszukać szeregu klasyfikacji eventów, w zależności od różnorodności kryteriów (Marczak, 2015; Cieślikowski, Kantyka, 2015). Jednego z pierwszych podziałów dokonał D. Getz (1997), który wyodrębnił: uroczystości kulturalne, wydarzenia polityczne-państwowe, królewskie, biznesowe i handlowe, edukacyjne i naukowe, sportowe i prywatne. 
Wydarzenia o charakterze kulturalnym, rozrywkowym oraz sportowym są istotnym elementem wpływającym na rozwój lub też utrzymanie pozycji miasta w zakresie turystyki kulturowej. Stanowią one obecnie jedną z głównych kategorii produktu turystycznego, jest to także nowoczesna forma promocji marki i produktu, ułatwiająca dotarcie do nowych klientów. Z pojęciem eventu bezpośrednio wiąże się zagadnienie turystyki eventowej. Mianem tym określa się podróże, których celem jest udział uczestników w specjalnie inscenizowanych imprezach o charakterze kulturalnym, mających ograniczony czas trwania i przyciągających turystów (von Rohrscheidt, 2010).

Zagadnienia turystyki eventowej lub wydarzeń są analizowane w różnych zakresach. Coraz częściej podkreśla się fakt, że eventy jawią się jako zjawiska charakterystyczne dla ponowoczesnej kultury, a nawet pojawia się określenie „eventyzacja współczesnej kultury” (Zduniak, 2017). Eventy to nie tylko dostarczanie rozrywki i poznawanie kultur, ale także możliwość rozwoju społecznego i nawiązywania nowych znajomości. Ten rodzaj spędzania wolnego czasu jest współcześnie jedną z najczęściej wybieranych form rozrywek przez społeczeństwo.

Prowincja Pistoia jest położona w północnej Toskanii - jednym z najważniejszych i najczęściej odwiedzanych regionów Włoch. Znajduje się tu 6 obiektów wpisanych na Listę światowego dziedzictwa UNESCO: historyczne centrum Florencji (1982), plac katedry w Pizie (1987), historyczne centrum San Gimignano (1990), historyczne centrum Sieny (1995), centrum miasta Pienza (1996) oraz dolina Val d'Orcia (2004). Toskania jest jednym z najważniejszych europejskich ośrodków kulturalno-artystycznych - znajduje się tu ponad 550 muzeów i galerii, a więc ponad 10\% wszystkich włoskich muzeów.

Ryc. 1. Położenie Pistoi na mapie Toskanii

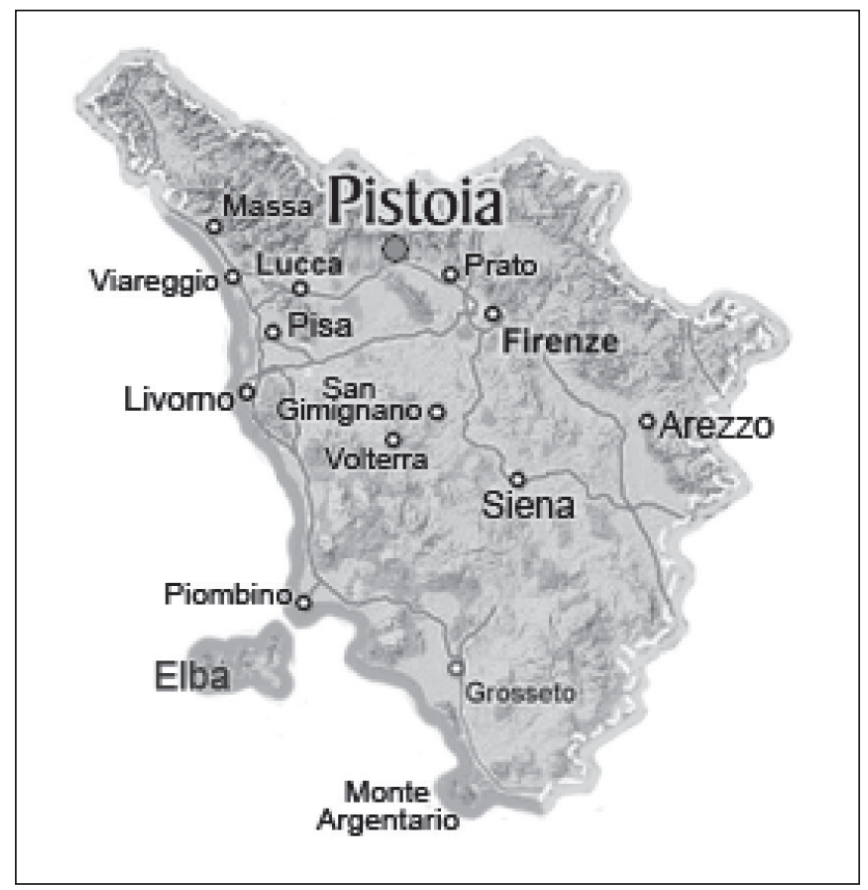

Źródło: https://www.discovertuscany.com/pistoia/ 
Sama stolica regionu - Florencja - uznana jest za „miasto bestseller” i jedno z 20 najważniejszych miast sztuki na świecie (Borg van der, Costa and Gotti, 1996). Przyciąga ona największą liczbę turystów w regionie - 9,2 mln, w tym 3,5 mln turystów zagranicznych (2016 r., http://www.lastampa.it/2016/07/18/societa/viaggi/italia/italia-troppi-turisti-le-citt-vogliono-il-numero-chiuso), a słynna Galeria degli Uffizi jest jednym z najważniejszych muzeów świata. Poza Florencją, głównymi ośrodkami artystycznymi Toskanii są Siena, Piza i Lukka. W Pizie co roku 10 mln turystów ogląda 55-metrową Krzywą Wieżę (Jędrusik, Makowski, Plit, 2010).

Prowincja Pistoia zajmuje $964 \mathrm{~km}^{2}$ powierzchni i graniczy na północy z prowincjami Modena i Bolonia, na wschodzie z prowincją Prato, na południu z prowincją Florencja i Piza, a na zachodzie z prowincją Lukka (ryc. 1). Pistoia liczy 22 gminy, spośród których największą i najbardziej znaczącą jest gmina Pistoia, ze stolicą prowincji - urokliwym, miastem Pistoia.

Pistoia jest średniowiecznym miastem, którego początki sięgają czasów antycznych, bardziej odległych od początków Florencji. Dzięki licznym liguryjskim i pseudoliguryjskim znaleziskom archeologicznym wiadomo, że dolina, w której zlokalizowane jest miasto, była zamieszkiwana już od II wieku p.n.e. Miasto prawdopodobnie zostało założone w 187 r. p.n.e. przez rzymskich żołnierzy Flaminiusza, którzy rozbili w tym miejscu obóz, by zaopatrzyć się w żywność podczas wojen z Ligurami. Nazwa miasta pochodzi również z czasów rzymskich, od słowa pistoria, które po łacinie znaczy 'piec do pieczenia chleba’. Przyjmowano także pochodzenie nazwy miasta od dwóch terminów etruskich: „Pist” i „Oros”, które miały znaczyć kolejno 'brama' i 'góra' (Tigri, 1990). W następnych wiekach Pistoia przechodziła z rąk rzymskich w ręce Gotów, Longobardów, Franków. Pod koniec XI w. zaczęła się w niej formować instytucja gminna, a po wojnach prowadzonych z Florencją, Lukką i Bolonią znacznie poszerzyła swoje terytorium. Od chwili sprowadzenia do Pistoi w 1144 r. relikwii św. Jakuba miasto stało się obowiązkowym przystankiem pielgrzymów podążającym szlakiem Via Francigena, a także tych udających się do Sanktuarium Santiago de Compostela. Niestety, w XIV w. w wyniku wewnętrznych sporów toczących się między bogatymi rodzinami Pistoi i wojen prowadzonych z sąsiednimi miastami Lukką i Florencją, miasto pogrążyło się w nędzy. Dopiero w XVII i XVIII w. nastały dla niego lata bogactwa i rozwoju, które przywróciły mu dawną rolę strategicznego punktu w handlu między środkowymi a północnymi Włochami. W 1861 r. Pistoia przyłączyła się do Królestwa Włoch (D’Afflitto, Falletti, 1999).

Pistoia chlubi się licznymi zabytkami o dużym znaczeniu historycznym i artystycznym, które zlokalizowane są w obrębie średniowiecznego Starego Miasta. Znajduje się tutaj 65 zabytków architektury i budownictwa, z czego 18 budowli to średniowieczne, renesansowe i barokowe kościoły. Najpiękniejszym z nich jest katedra św. Zenona, w której znajduje się najcenniejszy zabytek miasta - srebrny ołtarz św. Jakuba, arcydzieło średniowiecznej sakralnej sztuki złotniczej, w którym znajdują się relikwie świętego. Cechą miasta jest występowanie kilku przepięknych placów otoczonych wspaniałą ramą zabytkowych pałaców i kamienic. W mieście znajduje się 15 muzeów położonych w odległości około $100 \mathrm{~m}$ od siebie, 6 bibliotek i 6 obiektów z historycznymi archiwami, a także 15 hoteli mieszczących się w zabytkowych kamienicach (http://www.comune.pistoia.it/1917/ Musei-e-biblioteche). Na dziedzictwo Pistoi składa się również 50 stowarzyszeń o charakterze kulturalnym, z których 15 zajmuje się muzyką. 
Zagospodarowanie turystyczne oraz ruch turystyczny

Obecna baza noclegowa Pistoi charakteryzuje się dużym zróżnicowaniem, począwszy od luksusowych rezydencji, hoteli, przez bed \& breakfast, kwatery prywatne, domy i mieszkania wakacyjne, po gospodarstwa agroturystyczne. Według materiałów Urzędu Statystycznego Prowincji Pistoia w 2011 r. w gminie zarejestrowane były 82 obiekty noclegowe z 1593 miejscami noclegowymi (w 2008 r. - 1376). Spośród 16 hoteli kategorią dominującą są hotele trzygwiazdkowe z 498 miejscami noclegowymi, stanowiącymi 31,3\% ogółu miejsc noclegowych, i hotele czterogwiazdkowe ze 170 miejscami noclegowymi, które stanowią 10,7\% ogółu miejsc. Wśród pozostałych obiektów noclegowych dominują bed \& breakfast (24) i gospodarstwa agroturystyczne (23). Jednak biorąc pod uwagę ilość miejsc noclegowych, wyróżniają się rezydencje zabytkowe (5), które oferują 227 miejsc i są czynne przez cały rok. Najmniejszą liczbę miejsc oferują pokoje gościnne, jedynie 5,1\% ogółu miejsc. Całoroczne miejsca noclegowe stanowią 90,4\%.

W gminie Pistoia funkcjonuje ok. 190 placówek gastronomicznych, w tym 40 restauracji, 113 barów, 18 pizzerii i 19 punktów gastronomicznych. Większość obiektów jest zlokalizowana w centrum miasta, a największa ich koncentracja występuje w okolicy Piazza del Duomo, jednego z najpiękniejszych placów Włoch, gdzie można skosztować dań kuchni toskańskiej, lokalnych specjałów i najlepszych win. Sam standard jest zróżnicowany, co znajduje swoje odbicie w cenach.

Urządzenia bazy towarzyszącej mają znaczenie uzupełniające, ale są niezbędne dla podniesienia atrakcyjności turystycznej danego obszaru i pełniejszego wykorzystania jego walorów. Na terenie Pistoi w ostatnich latach nastąpił wyraźny i dynamiczny rozwój usług rekreacyjnych. Infrastruktura sportowo-rekreacyjna dostosowana jest do potrzeb turystów, stwarzając im dogodne warunki do podejmowania różnych form rekreacji i rozrywki. Liczne obiekty sportowo-rekreacyjne umożliwiają uprawianie różnorodnych dyscyplin sportowych, jak i uczestniczenie w zorganizowanych imprezach masowych. Na terenie gminy znajdują się 2 korty tenisowe, 3 boiska do siatkówki i koszykówki, basen i 13 siłowni zlokalizowanych w samym mieście, ścianki wspinaczkowe, poligon do strzelania $\mathrm{z}$ łuku, tor samochodowy, stadion atletyczny, 4 lodowiska oraz 20 klubów sportowych. Miasto oferuje turystom bogaty repertuar w 3 teatrach, 3 kinach oraz filharmonii, a także bogactwo zbiorów oryginalnych dzieł sztuki i innych eksponatów w 15 muzeach.

Pistoia jest miastem, do którego potencjalny turysta może z łatwością dotrzeć dzięki autostradzie A11, połączonej z krajową siecią autostrad Florencja-Morze. Oprócz połączenia autostradowego do miasta można dotrzeć drogą krajową 64 Porrettana, łączącą ją z miastami w regionie Emilia-Romania i Ferrara, drogą regionalną 66 Pistoiese, która łączy ją z Florencją i drogą krajową 12 dell’Abetone i dell Brennero oraz drogą regionalną 435 Lucchese, łączącą ją z zachodnią Toskanią (Ruozi, 2009). Pistoia i wszystkie miejscowości prowincji są osiągalne dzięki wygodnym liniom autobusowym Lazzi, Copit i CAP (www.lazzi.it). W prowincji Pistoia nie ma lotnisk cywilnych. Najbliżej położone to lotnisko Galileo Galilei w Pizie oraz Amerigo Vespucci we Florencji.

Pistoia oddaje do dyspozycji turysty i mieszkańca wygodny system Park \& Bus, zespół parkingów z przesiadką na komunikację wahadłową, który daje możliwość zaparkowania samochodu w różnych częściach miasta i dotarcie do centrum komunikacją miejską. Pistoia od zawsze popierała inicjatywy dotyczące alternatywnej i ekologicznej komunikacji, dlatego też uruchomiła serwis automatycznego wypożyczania rowerów, finansowany 
przez Ministerstwo Środowiska. Serwis ten nazywa się „Pistoia na rowerze”. Za pomocą elektronicznej karty można w nim skorzystać z prawie 40 rowerów umieszczonych w stojakach w obrębie historycznego centrum miasta.

Pistoia, pomimo dobrej dostępności komunikacyjnej, położenia w sąsiedztwie znanych ośrodków turystycznych o renomie międzynarodowej, bogactwa architektonicznego i kulturalnego Starego Miasta, jego niezwykłej atmosfery i gościnności, a także wysokiej jakości zróżnicowanej infrastruktury turystycznej, przyciąga ciągle małą liczbę turystów. W ciągu ostatniego dziesięciolecia najwięcej turystów przyjechało w 2000 r. 64 674, z czego turystów zagranicznych - 23 369. W latach 2001-2004 następował ciągły spadek liczby turystów do poziomu 34 927, z czego turyści zagraniczni to zaledwie 11 467. W 2010 r. liczba turystów zwiększyła się do 49 940, z czego 20611 to turyści zagraniczni. Przyrost liczby turystów nastąpił również w następnym, 2011 r. do 52 270, z czego turystów zagranicznych było 21 320. Dla porównania: w 2011 r. Pizę odwiedziło 646914 turystów, Lukkę - 241540 turystów, Prato - 190927 turystów, a Florencję - 3257061 turystów (www.regione.toscana.it). Z danych statystycznych wynika, że w Pistoi przeważa krajowy ruch turystyczny. Wśród turystów krajowych najliczniejszą grupę stanowią turyści z Lombardii, Lacjum i Toskanii. Dane te potwierdzają wyniki badań prowadzonych przez C. Massidda i I. Etzo (2012), dotyczących włoskiej turystyki krajowej. Biorąc pod uwagę kraj pochodzenia turystów zagranicznych liderami są obywatele Niemiec, Francji, Holandii i Wielkiej Brytanii, a spoza Europy - obywatele USA. Pistoia popularna jest również wśród mieszkańców innych krajów europejskich, takich jak Belgia, Hiszpania, Szwajcaria, Lichtenstein, Dania, Austria i Polska. Najczęściej wybieranymi obiektami noclegowymi przez turystów w latach 2000-2010 były hotele trzy- i czterogwiazdkowe. Dużą popularnością cieszyły się również gospodarstwa agroturystyczne oraz rezydencje zabytkowe (www.provincia.pistoia.it). Średnio turyści przebywają w Pistoi 2,8 dnia, a więc podobnie jak w większości innych miast dziedzictwa europejskiego (Costa, van der Borg, 1992; van der Borg, Costa, Gotti, 1996).

Cechą charakterystyczną turystyki przyjazdowej w gminie Pistoia jest jej sezonowość. Największa liczba noclegów udzielonych turystom krajowym i zagranicznym ma miejsce w okresie od czerwca do października. Jest to oczywiście związane z okresem wakacyjnym i urlopowym, najkorzystniejszymi warunkami wypoczynkowymi oraz występującymi w lipcu i sierpniu największymi imprezami kulturalnymi (www. provincia.pistoia.it).

\section{Eventy jako elementy produktu turystycznego Pistoi}

Wzmożony rozwój turystyki na świecie, obserwowany przez pryzmat zwiększającego się ruchu turystycznego oraz zagospodarowania turystycznego, zmusza do działań konkurencyjnych. Konkurencyjność regionów lub ośrodków turystycznych należy rozumieć jako zdolność obszaru do rywalizacji z innymi w zakresie przyciągania ruchu turystycznego. Szczególnie trudna sytuacja występuje, kiedy muszą konkurować ze sobą jednostki przestrzenne o podobnych, a wręcz identycznych produktach turystycznych, ale znacznie różniących się wielkością. Tak jest w przypadku Pistoi, która jest miastem historycznym i musi rywalizować ze znacznie większymi oraz bardziej znanymi miastami leżącymi w jej sąsiedztwie - Florencją i Pizą, w których komercjalizacja i umasowienie turystyki są cechami charakterystycznymi. W związku z tym dochodzi do pewnej polaryzacji - obszary masowego i skoncentrowanego ruchu turystycznego są w opozycji do średnich i małych 
miast o dużym potencjale turystycznym, które przegrywają wyścig z gigantami rynku turystycznego o zainteresowanie turystów. W artykule M. Teobaldiego i C. Capineriego (2014) porównano to zjawisko do koncepcji stosowanej w marketingu tzw. „długiego ogona”, w której to najpopularniejsze destynacje (Florencja, Piza) stanowią „krótką głowę”, tzw. hon, natomiast rzadziej odwiedzane miasta stanowią „długi ogon”, ale one proponują produkty niszowe przeznaczone dla stosunkowo wąskiej grupy odbiorców (Lew, 2008).

To wymusza większą aktywność marketingową miast jako podmiotów rynku turystycznego, m.in. w tym celu wykorzystywane są wydarzenia o różnym charakterze jako element strategii promocyjnej. Wydarzenia (eventy) są jedną z form public relations, która pozwala kreować pozytywny wizerunek miasta i wyróżnić się na tle konkurencji (Cieślikowski, Kantyka, 2015). Promocję w marketingu terytorialnym miast turystycznych można zdefiniować jako całokształt działań związanych z komunikowaniem się jednostki terytorialnej z otoczeniem, obejmujący informowanie o walorach turystycznych, przekonywanie o jego atrakcyjności i skłanianie do nabycia lub konsumpcji subproduktów terytorialnych (Florek, 2006). Zastosowanie zasad marketingu w zarzadzaniu miastem może pozwolić na celowe i właściwe, ukierunkowane wykorzystanie posiadanego przez daną jednostkę terytorialną potencjału, co w konsekwencji prowadzi do osiągnięcia przewagi konkurencyjnej (Zdon-Korzeniowska, 2011). Wydarzenia pomagają kreować pozytywny wizerunek destynacji oraz ułatwiają dotarcie do różnych grup odbiorców.

Na przestrzeni ostatnich lat odnotowano w Pistoi szereg działań w sferze organizacji różnego rodzaju eventów, zwłaszcza o charakterze kulturalnym, rozrywkowym i naukowym, które przyciągają coraz większą liczbę turystów. Przez cały rok odbywają się tu uroczystości historyczne i religijne, imprezy ludowe, festiwale, targi i uczty zakorzenione w kulturze mieszkańców Toskanii, oferujące nieskończone możliwości tym, którzy chcą zanurzyć się w tysiącletniej historii prowincji oraz miasta. Podczas tych wydarzeń oferowane są produkty i typowe potrawy lokalne (Briganti, 2004).

Do najbardziej znanych eventów, stanowiących główny bodziec przyjazdu licznej grupy turystów, należy organizowany corocznie w lipcu Pistoia Festival. Oferuje on wiele muzycznych, filmowych, literackich i tradycyjnych wydarzeń. Najważniejszym jednak jest Pistoia Blues Festival, który należy do jednych z najbardziej znanych imprez bluesowych na świecie. Festiwal organizowany jest od 1980 r. przez Stowarzyszenie Pistoia Blues i miasto Pistoia we współpracy z regionem Toskanii. Każdego roku, przez trzy wieczory lipcowe, przyciąga on coraz więcej widzów, jak i wielkich artystów. Występowali tu m.in. Chuck Berry, Frank Zappa, Jimmy Page, Carlos Santana, Van Morrison, Joe Satriani, Bob Dylan, Lou Reed, David Bowie, Robert Plant i wielu innych (https://www.toscanainside. com/events-in-tuscany/great-events/pistoia-blues-festival/). Festiwal ten, podobnie jak inne tego typu wydarzenia, przyczynia się do promocji miasta, a jednocześnie do zwiększenia popytu na lokalne towary i usługi (Attanasia i in., 2013).

Równie popularny jest historyczny turniej Giostra dell'Orso lub Joust of the Bear, który od 1947 r. odbywa się zawsze 25 lipca, w święto patrona miasta św. Jakuba na głównym placu Piazza del Duomo. Jest to turniej jeździecki, w którym rywalizują przedstawiciele czterech historycznych dzielnic miasta. Z tej okazji plac przekształca się w owalny tor wyścigowy, otoczony przez trybuny, z których wydarzenie może podziwiać ok. 4,5 tys. widzów. Wyścigowi towarzyszą uroczysta parada rycerzy i koni przez miasto oraz msza w katedrze ku czci św. Jakuba (http://www.italia.it/en/discover-italy/tuscany/pistoia.html). Jedną z ważniejszych, a nie do końca wykorzystanych atrakcji turystycznych, 
jest kult św. Jakuba i fakt pielgrzymowania. Patronem miasta jest św. Zenon, ale kiedy w 1144 r. za sprawą biskupa Atto sprowadzono do miasta z Santiago de Compostela relikwie św. Jakuba, to on stał się najważniejszym patronem.

W gminie Pistoia turystyka jest sektorem mocno rozwijającym się, a uwaga władz miasta koncentruje się na wzmocnieniu jego wizerunku jako „Miasta sztuki i kultury” oraz polepszeniu usług turystycznych (www.comune.pistoia.it). W przypadku turystyki kulturowej problemem jest mądre wykorzystanie dziedzictwa w rozwoju turystyki, zgodnie z ogólnymi zasadami zrównoważonego rozwoju. Wyzwaniem dla mniejszych miast, które chcą być docelowymi punktami turystyki kulturowej, jest znalezienie równowagi między identyfikacją unikalnych dóbr kultury a ich wyrafinowanym sposobem sprzedania opinii publicznej. Sugeruje to potrzebę podejścia zintegrowanego w promocji mniej znanych ośrodków kulturowych, co może być bardziej skuteczne niż koncentracja wysiłku na „supergwiazdach” (Cuccia, Rizzo, 2010). W przypadku miast, w których wartość dóbr kultury nie wystarcza do rozwoju opłacalnego przemysłu turystycznego, istniejące zasoby kultury muszą być promowane w połączeniu $\mathrm{z}$ innymi atrakcjami turystycznymi, takimi jak wydarzenia, gastronomia, wysokiej jakości infrastruktura, bez utraty z pola widzenia oryginalnego i atrakcyjnego wizerunku (Russoa, van der Borg, 2002).

O autentyczności Pistoi i regionu świadczą również liczne stowarzyszenia wspierające małych, lecz cenionych producentów oraz rzemieślników tradycyjnych zawodów. Przykładem są rzemieślnicy wytwarzający tradycyjne wyroby czekoladowe w tzw. Toskańskiej Dolinie Czekolady, która rozciąga się pomiędzy Pizą, Pistoią a Prato. Autentyczność przejawia się także w prostej - rustykalnej kuchni opartej na typowo lokalnych tradycjach i niezmienionych składnikach. Jej elementem są lokalne wina wysoko notowane daleko poza granicami regionu.

Pistoia znana jest również z działalności szkółkarskiej, w której zdobyła tytuł Europejskiej Zielonej Stolicy. Typowe produkcje wywodzą się z tradycji toskańskich farm renesansowych. Szczególnie Pistoia znana jest z produkcji roślin o różnych kształtach, służących do wyposażania ogrodów.

Satysfakcja i dobre samopoczucie turysty mogą być pośrednio wykorzystane do oceny konkurencyjności danego miejsca (regionu turystycznego). Atrakcyjność odnosi się tutaj do dobrej dostępności, jakości i zarządzania lokalnymi usługami turystycznymi, zaspakajania potrzeb klienta, czyli do osiągnięcia turystycznego dobrobytu. Badania empiryczne, przeprowadzone przez Cracoliciego i Nijkampę (2008) w regionach turystycznych południowych Włoch pokazują, że nie zawsze wielkość ruchu turystycznego jest równoznaczna z satysfakcją turysty. Zła jakość oferowanych usług może w dłuższej perspektywie zagrozić pozycji konkurencyjnej regionu na rynku turystycznym. Natomiast dobre wyniki jakościowe mogą stanowić dla regionu podstawę do poprawy jego pozycji konkurencyjnej na rynku.

Pistoia jest miastem, którego sztuka i kultura czekają na to, by je odkryć, a pozostałe bogactwo atrakcji, które nie jest jeszcze należycie udostępnione i poznane przez szeroką publikę - by je docenić (Ruozi, 2009). Należy również uczynić ofertę turystyczną bardziej interesującą przez promowanie tożsamości tego miasta, na którą składają się trzy główne składniki:

- historia, sztuka, kultura, lokalne tradycje,

- rzemiosło, wysokiej jakości lokalne produkty,

- zróżnicowane środowisko przyrodnicze. 
Te trzy składniki stanowią siłę gminy i samego miasta, a Pistoia jak najbardziej zasługuje na to, aby znaleźć stałe miejsce na szlaku podróżnika nowego typu, który kieruje się głównie do średnich i małych miast, nieskażonych jeszcze turystyką masową (Mariotti, Romei, 2009). W tej tak dynamicznej rzeczywistości znajduje się jeszcze przestrzeń dla turystyki niszowej, oferującej usługi wysokiej jakości, jednocześnie proste i autentyczne, tym, którzy potrafią docenić niepowtarzalne bogactwa lokalne.

Nie można zapominać, że nie tylko bogactwo historyczno-architektoniczne stanowi o atrakcyjności danego miasta. Ta siła przyciągania jest wypadkową wielu elementów, ponieważ każde miasto ma wiele twarzy: historyczną, architektoniczną, kulturalną, handlową czy tą związaną z szeroko rozumianą rozrywką. Biorąc pod uwagę wyżej wymienione czynniki, można stwierdzić, że Pistoia jest miastem, gdzie w sposób optymalny wykorzystuje się zaplecze historyczne i kulturowe oraz zasoby naturalne.

Mając na uwadze posiadany potencjał materialny dla organizowania wydarzeń, jak również rozpoczęte inwestycje zmierzające do rewitalizacji przestrzeni miejskiej, władze Pistoi podjęły działania zmierzające do przyciągania wydarzeń o znacznie szerszym zasięgu niż tylko lokalne. W związku z tym skoncentrowano się na wydarzeniach o zasięgu krajowym, a do takich należy idea Włoskich Miast Kultury. Kandydatura Pistoi jako Włoskiej Stolicy Kultury w 2017 r. była popierana przez władze terytorialne różnych szczebli (the Municipality of Pistoia, the support of the Region of Toscana). Pistoia oparła swoją kandydaturę na przekonaniu, że miasto musi nieustannie dbać o jakość życia mieszkańców i jakość odpoczynku turystów. W związku z tym w latach poprzedzających kandydowanie zdecydowano się zainwestować w szereg projektów kulturalnych. Według władz miasta, poziom inwestycji w projekty kulturalne jest dwukrotnie wyższy niż średnia krajowa (http://www.pistoia17.it/en/the-project). Działanie to ma swoje uzasadnienie w twierdzeniu, że dostęp do różnych projektów i wydarzeń o charakterze kulturalnym jest najważniejszym prawem społeczeństwa, co w konsekwencji sprzyja edukacji świadomych i zaangażowanych obywateli miasta. To także decyduje, że zmienia się miasto, ludziom żyje się tutaj dobrze, a to powoduje wzrost zainteresowania turystów, którzy „zaliczyli” ważne atrakcje, chcą odpoczywać w ciszy i spokoju, delektując się niespiesznym życiem miasta i jego mieszkańców.

Pozytywnym zjawiskiem towarzyszącym organizacji eventów w Pistoi jest kształtowanie pozytywnych relacji pomiędzy mieszkańcami a turystami. Współcześnie obserwujemy szereg niepokojących sytuacji, w których dochodzi do konfliktów pomiędzy tymi dwiema grupami (syndrom wenecki). Rozwój kulturalny miasta powinien być rozpatrywany w dwóch aspektach, tj. pod kątem potrzeb i aspiracji mieszkańców oraz potencjalnych turystów. Pistoia jest przykładem miasta, w którym podejmowanych jest szereg inicjatyw obywatelskich w porozumieniu $\mathrm{z}$ władzami miejskimi, zmierzających do poprawy jakości życia mieszkańców miast historycznych, którzy muszą borykać się z szeregiem ograniczeń (zabytkowa zabudowa). Jedną z takich inicjatyw jest UAPC - Un altro parco in città - program rozpoczęty w 2012 r., który dotyczy zachowania i rozwijania terenów zielonych w mieście. Pistoia jest unikatowym na skalę całych Włoch miastem, w którym tereny zielone, a w szczególności użytki rolne, mają pokaźny udział. W Pistoi obserwuje się tendencję do powiększania trenów zielonych - w ciągu trzech ostatnich lat pozyskano 5 ha gruntów, które zostaną przeznaczone pod parki i ogrody. 


\section{Podsumowanie}

To właśnie konkurencja sławnych sąsiadów o międzynarodowym znaczeniu, którymi są Florencja, Piza czy trochę mniej znane Lukka i Prato, powoduje, że Pistoia pomimo swojego bogactwa historyczno-architektonicznego, dobrego zagospodarowania turystycznego i dobrej dostępności komunikacyjnej jest jeszcze jednym z rzadziej odwiedzanych przez turystów miast Toskanii. Jednym z rozwiązań zaistniałej sytuacji jest organizacja wydarzeń, których celem będzie uwypuklenie wszystkich aspektów potencjału tego miejsca: architektury, sztuki, tradycji, folkloru i kultury materialnej, gdyż wszystkie one są świadectwem jego autentycznego i indywidualnego charakteru. Miasto oferuje bogatą spuściznę artystyczną powiązaną z muzyką, systemem wystaw i wydarzeń, centrum historyczne ze zorganizowanymi przestrzeniami zieleni, ogrodami, rozwiniętym systemem handlowym, siecią usług, informacją turystyczną i usługami przewodnickimi na wysokim poziomie. Ma również ciekawe propozycje w zakresie wybranych dziedzin życia społeczno-kulturalnego, charakterystycznych dla wysokorozwiniętych populacji wielkich metropolii, jako teren przyjazny dla człowieka, miejsce regenerujące slow living. Można tu wysłuchać koncertu organowego w jednym z kościołów romańskich, odwiedzić szkółkę hodowlaną roślin dekoracyjnych, podziwiać nowe odmiany róż i krzewów ozdobnych, by następnie wybrać się w podróż „Szlakiem Oliwy i Wina” czy też „Szlakiem Zapachów i Kolorów Appennino Pistoiese". Wydarzenia/eventy organizowane w Pistoi mogą w przyszłości skutkować zwiększoną liczbą turystów krajowych i zagranicznych, ale czy ta tendencja nie spowoduje zaniku autentyczności tak charakterystycznej dla tego miasta, w którym po prostu się mieszka?

Literatura

References

Attanasia, I.G., et al. (2013). Cultural investment, local development and instantaneous social capital: A case study of a gathering festival in the South of Italy. The Journal of Socio-Economics. DOI: 10.1016/j.socec.2013.05.014

Briganti, D. (2004). Pistoia guida della citta. Pistoia: Edimond.

Cieślikowski, K., Kantyka, J. (2015). Wykorzystanie wielkich wydarzeń w promocji miasta - na przykładzie Katowic. Zeszyty Naukowe Uczelni Vistula 40, 29-41.

Costa, P., van der Borg, J. (1992). The Management of Tourism in Cities of Art. Vrije Tijd en Samenleving, $10(2 / 3), 45-57$.

Cuccia, T., Rizzo, I. (2010). Tourism seasonality in cultural destinations: Empirical evidence from Sicily. Tourism Management, 32, 589-595.

D’Afflitto, Ch., Falletti, F. (1999). Pistoia e il suo territorio. Calenzano: Mondadori.

Florek, M. (2006). Podstawy marketingu terytorialnego. Poznań: Wydawnictwo Akademii Ekonomicznej.

Getz, D. (1997). Event management \& event tourism. New York: Cognizant Communication Corp.

Jędrusik, M., Makowsk, J., Plit, F. (2010). Geografia turystyczna świata. Nowe trendy. Regiony turystyczne. Warszawa: Wydawnictwo Uniwersytetu Warszawskiego.

Lew, A.A. (2008). Long tail tourism: New geographies for marketing niche tourism products. Journal of Travel \& Tourism Marketing, 25(3-4), 409-419.

Marczak, M. (2015). Eventy jako produkty turystyki kulturowej na przykładzie miasta Kołobrzeg. Zeszyty Naukowe Wydziału Nauk Ekonomicznych, 19, 103-120.

Mariotti, I., Romei, P. (2009). Turismo a Pistoia. Pistoia: Comune di Pistoia. 
Massidda, C., Etzo, I. (2012). The determinants of Italian domestic tourism: A panel data analysis. Tourism Management, 33, 603-610.

Melani, V. (2005). Pistoia. Pistoia: Tellini.

Ruozi, R. (2009). Pistoia e provincia. Pistoia: Touring Club Italiano.

Russoa, A.P., van der Borg, J. (2002). Planning considerations for cultural tourism: a case study of four European cities. Tourism Management, 23, 631-637.

Teobaldi, M., Capineri, C. (2014). Experiential tourism and city attractiveness in Tuscany. Rivista Geografica Italiana, 121(3), 259-274.

Tigri, G. (1990). Pistoia e il suo territorio. Bologna: Atesa.

van der Borg, J., Costa, P., Gotti, G. (1996). Tourism in European Heritage cities. Annals of Tourism Research, 23(2), 306-321.

von Rohrscheidt, A.M. (2010). Turystyka kulturowa: fenomen, potencjał, perspektywy. Poznań: Wydawnictwo KulTour.pl.

Zdon-Korzeniowska, M. (2011). Marketing terytorialny jako forma działań przedsiębiorczych samorządów terytorialnych w Polsce. Przedsiębiorczość - Edukacja, 7, 188-196.

Zduniak, A. (2017). Event jako ponowoczesna forma uczestnictwa w życiu społecznym. Roczniki Nauk Społecznych, 38(1), 207-234.

Renata Rettinger, doktor/adiunkt w Instytucie Geografii, Zakładzie Turystyki i Badań Regionalnych Uniwersytetu Pedagogicznego w Krakowie. Autorka w swoich badaniach koncentruje się na problematyce rozwoju turystyki w regionie karaibskim. W podejmowanej przez nią problematyce badawczej przeważają tematy dotyczące wielkości i przestrzennego zróżnicowania zagospodarowania i ruchu turystycznego, a w szczególności kierunków rozwoju turystyki. W opracowaniach pojawia się także tematyka enklaw turystycznych jako dominującej formy zagospodarowania turystycznego na Karaibach w kontekście rozwoju zrównoważonego i turystyki pro-poor.

Renata Rettinger, $\mathrm{PhD}$, assistant professor in Institute of Geography, Department of Tourism and Regional Studies at the Pedagogical University of Cracow. In her research, the author concentrates on the problems of tourism development in the Caribbean region. The research issues on the size and spatial differentiation of tourist infrastructure and tourism volume itself together with the directions of the tourism development dominate. The research topics also include the issue of tourist enclaves as a dominating form of tourist infrastructure in the Caribbean in the light of sustainable development and pro-poor tourism.

\section{Adres/Address:}

Uniwersytet Pedagogiczny im. Komisji Edukacji Narodowej w Krakowie Instytut Geografii

Zakład Turystyki i Badań Regionalnych

ul. Podchorążych 2

30-084 Kraków, Polska

e-mail: rettinger@up.krakow.pl

Małgorzata Bajgier-Kowalska, doktor/adiunkt na Wydziale Prawa, Administracji i Stosunków Międzynarodowych, w Katedrze Turystyki Międzynarodowej i Geografii Społecznej Krakowskiej Akademii im. Andrzeja Frycza Modrzewskiego. Jej zainteresowania naukowo-badawcze i tematyka publikacji koncentrują się wokół problemów geomorfologicznych oraz zagadnień z zakresu geografii regionalnej. Autorka zajmuje się również problematyką rozwoju turystyki i rekreacji, głównie uwarunkowaniami rozwoju i funkcjonowania regionów turystycznych na świecie, analizą przestrzennego zróżnicowania zagospodarowania turystycznego oraz wielkości ruchu turystycznego.

Małgorzata Bajgier-Kowalska, PhD, assistant professor at the Andrzej Frycz Modrzewski Krakow University, Faculty of Law, Administration and International Relations, Department 
of International Tourism and Sociological Geography. Research issues as well as publication themes are concentrated on geomorphology problems and the issues concerning regional geography. Author's research concentrates also on the problem of tourism and recreation growth, especially on development conditions and functioning of tourist regions in the world including the analyses of spatial differentiation of tourist infrastructure and size of tourism itself.

\section{Adres/Address:}

Krakowska Akademia im. Andrzeja Frycza Modrzewskiego

Wydział Prawa, Administracji i Stosunków Międzynarodowych

ul. Gustawa Herlinga-Grudzińskiego 1

30-705 Kraków, Polska

e-mail: malbajkow@interia.pl 